\title{
Strategy Analysis on the Integration of Traditional Teaching and 020 Mode to Improve the Construction Quality of Teaching Professional Resource Database
}

\author{
Xiao Yin* \\ Ji Lin Justice Officer Academy, Changchun 130062, Jilin, China. \\ E-mail: seekeryin@sina.com
}

Project: Research project of vocational education and adult education teaching reform in Jilin Province in 2019: Research on the application of online and offline hybrid teaching and professional teaching resource database based on 020 model (Project No.: 2019zcy188)

\begin{abstract}
Ministry of Education of the People's Republic of China launched the Construction of National Vocational Education Teaching Resource Database project in 2010, vocational colleges have joined 020 mode on the basis of traditional teaching and achieved the goal of steadily improving the construction of teaching professional resource database, in addition, promoted the first landing of Internet + Education in the field of higher vocational education. However, there are still some problems in the construction of professional resources and the quality of teaching resources. The purpose of this paper is to analyze the current situation and shortcomings of the construction of teaching professional resource database in higher vocational colleges and explore the construction methods of teaching professional resource database under the traditional teaching and 020 mode thinking, so as to promote the teaching reform.
\end{abstract}

Keywords: 020 mode; teaching professional resource database; Internet; teaching

After ten years of development, vocational education professional teaching resources database has been gradually improved in the continuous creation. Now it has built into 126 national resources and developed more than 4 million resources, covering 19 major categories, learning users of about 5.7 million with visited more than 1.5 billion times. It has achieved breakthroughs in talent training mode, teaching staff construction and teaching management reform in higher vocational education. The characteristics of higher vocational education are gradually forming. However, in the face of the growing development of the Internet and its widespread application in education, it is possible to integrate traditional teaching and 020 mode to improve the construction quality of teaching professional resource library, which has a positive role in promoting the construction of teaching professional resource database.

\section{1、Analysis on the current situation of the construction for teaching resources database in higher vocational colleges}

\subsection{The resource structure design of teaching professional resource database needs to be improved}

At present, there are abundant resources in the resource database of higher vocational college teaching specialty, but the design of resource structure is not reasonable and needs to be improved. From the perspective of teachers, students, enterprise employees and social learners, the purpose of using the resource database is to learn the professional courses as a whole and to learn the specialized knowledge in fragments. However, although the teaching professional resource database of higher vocational colleges covers a wide range and can meet the basic learning needs of the above-mentioned four categories of personnel, it still needs to be improved in terms of vocational skills training, innovation and entrepreneurship

Copyright (C) 2020 Xiao Yin

doi: $10.18282 /$ le.v9i6.1308

This is an open-access article distributed under the terms of the Creative Commons Attribution Non-Commercial License

(http://creativecommons.org/licenses/by-nc/4.0/), which permits unrestricted non-commercial use, distribution, and reproduction in any medium, provided the original work is properly cited. 
etc. In addition, the update speed is also difficult to adapt to the changes and development of economic society.

\subsection{Teaching professional resources database of vocational education resources need to be supplemented}

At present, the resource providers or creators of higher vocational college for teaching professional resource database are mostly higher vocational colleges and universities, and the participation of enterprises in related majors and industries is not high, accounting for only three fifths. The data shows that the teaching professional resource database involved by the enterprises for creation and construction, the content of vocational education is more abundant, and the applicability is wider. However, there are also some enterprises participating in the establishment and construction of teaching professional resource database, which has the characteristics of formalism. That is so say, the resources of vocational education need to be supplemented. More enterprises from related industries are required to participate in the construction and attach importance to the construction, so as to ensure the high quality of resources and improve the effect.

\subsection{The management and maintenance of teaching professional resource database need to be strengthened}

It has been more than ten years since the construction and development of teaching professional resource database. Due to the limited human resources and the lack of continuous updating management measures in higher vocational colleges and universities, the quality of teaching resources in some higher vocational colleges is not high, which is mainly manifested in the following aspects: first, the content structure is fragmented, lacking of systematicness and integrity; second, the content of text accounts for a relatively high proportion. Some video resources are also directly transformed into text content, lacking of innovation; third, the content fails to reflect the latest trends of the industry and divorces from economic change and social development as well as lacks wider applicability; fourth, virtual simulation resources are presented by software operation demonstration, so learners cannot really experience virtual experience, which is not conducive to learners' practical operation ability promote. It can be seen that the management and maintenance of teaching professional resource database needs to be strengthened, and all kinds of resources need to be continuously updated and constructed.

\section{2、Summary of the construction in teaching professional resource database under the traditional teaching and 020 mode thinking}

In 2012, the Ministry of Education issued the Ten Year Development Plan For Education Informatization (20112020), which proposed the construction of Three Links And Two Platforms, namely, broadband network school to school, high-quality resources class to class, online learning person to person, education resources cloud platform and education management service cloud platform. The World University City resource database based on this project plan is one of the best templates for Internet+ and $\mathrm{O} 2 \mathrm{O}$ technology application. It can be seen that under the traditional teaching mode and $\mathrm{O} 2 \mathrm{O}$ mode of thinking, the construction of teaching professional resource database has the possibility and feasibility of improving its quality.

\subsection{Deepening the integration of production and education, improving the design of resource structure}

The core of teaching reform under the guidance of 020 mode is to change the former teacher-centered teaching mode into student-centered teaching mode, so as to improve the quality of teaching service through platform construction and resource construction as well as enable students to construct an all ecological learning environment relying on Internet security environment through online and offline learning. Similarly, 020 model and traditional teaching can promote the construction of teaching professional resource database and improve the construction quality. The main method is to deepen the integration of production and education, and improve the design of resource structure. 020 mode teaching content aims at the development trend of national key industries and regional pillar industries, and creates relevant professional resource database according to the school's own positioning, also combines with teaching content and teaching resources. For example, colleges and universities are automobile vocational schools, which can create resource databases in the aspects of automobile intelligent manufacturing, intelligent Internet connected automobile, automobile automatic driving, and so on. In the 020 mode teaching, we can constantly find that the database is insufficient, and timely update and improve the relevant resource content, so as to improve the construction quality of the resource database.

\subsection{Deepen school enterprise cooperation, supplement vocational education resources}


The purpose of traditional education and 020 mode teaching is to improve the quality of teaching and improve the employment rate of students, which coincides with the purpose of professional resource database requiring enterprise participation. Therefore, based on the background of traditional education and 020 mode teaching, higher vocational colleges and universities can establish a deep cooperation relationship for school enterprise and meet the needs of enterprise employment, in order to develop online and offline courses and train student according to the requirement of enterprise, so as to enrich and supplement the vocational education resources of teaching professional resource database with such reform and innovation resources. The main methods include: first, to actively provide technical research and development support for enterprises, and guide students to actively participate in research and development; second, to deeply explore the employment needs of enterprises, and formulate teaching contents and plans according to the talent training plan. For example, the online and offline course system of Huawei is formulated according to Huawei's employment standards and the resource database is updated with the course content, at the same time, the 020 teaching content is upgraded with the content of the resource database.

\subsection{Keep up with the development of the industry, establish a long-term mechanism for resource database maintenance}

Whether it is the fragmentation of resource content or the scarcity of virtual simulation resources, in a word, it is the backwardness of resource content and the disconnection with teaching and related industries. Therefore, it is necessary to keep up with the industry and professional development trends and constantly update resources, data and information, so as to attract more users and maintain user on the basis of establishing a long-term mechanism for maintaining resource database.For example, in view of the problem that virtual simulation resources are presented by software operation demonstration but learners can't really experience it, online virtual simulation video can be watched and learned in teaching classroom. Certainly, the school can also build virtual simulation and other training materials based on the traditional training teaching of the school around the skills points and modules of the production process, and put them into the professional resource database to improve the resources and improve the quality of the resource database.However, it is worth noting that the virtual simulation resources cannot be operated on-site. Vocational colleges and universities can increase the external operation (VRS) system based on the original DCS system to realize the interaction between internal and external operations.

\section{Conclusion}

To sum up, there are some deficiencies in the construction of teaching professional resource database in higher vocational colleges, such as the structural design of teaching professional resource database needs to be improved, the vocational education resources need to be supplemented and managed, as well as the maintenance needs to be strengthened. Under the traditional teaching and 020 mode thinking, through deepening the integration of industry and education, enhancing school enterprise cooperation and following the industry trends, construction resources of teaching professional resource database will be improved, so do the construction quality of teaching professional resource database.

\section{References}

1. Li Yinchang, Meng Lisi. Online and offline mixed first-class curriculum design based on the construction of digital resource database -- taking industrial economics course as an example. Modern Vocational Education,2020(27):48-49.

2. Liang Qian, Jiang Sheng, Xie Xin, Huang Peng. Discussion on the construction and implementation of high level professional teaching resource library -- Taking the teaching resource library of centralized control operation of thermal power plant as an example. Journal of Wuhan Vocational and Technical College,2020,19(03):26-29.

3. Geng Heshang, Liu Zhonghui, Jiang Shanshan, Tian Qizhen, Lu Wei, Cao Bin. Based on the cloud classroom of smart vocational education, build a 'Cross Space, All-round' online and offline interactive hybrid teaching mode -taking modern pet technology teaching resource database as an example. Modern Agricultural Science and Technology, 2020(02):237-238.

4. Dai Luling. Construction and application of shared curriculum teaching resource database in higher vocational colleges--taking the course of refrigeration principle and device as an example. Training in China,2016(22):149-150.

5. Zuo Mingyang, Fang Jiuhua, Sun Huining, Jiang Yong. Research on the construction of teaching resource database of vocational education specialty under the concept of 'demand oriented' -- taking the construction of building materials resource database as an example. Journal of Wuhan Vocational and Technical College, 2020,19(03):20-25. 